\section{Science and the Manager}

By Prof. R. W. Revans. Pp. xi +160 . (London: Macdonald and Co. (l'ublishers), Ltd., 1965.) 25s. net.

$\mathrm{N}$ Science and the Manager, Prof. Revans has collected 1 eight essays, written during the past 20 years and addressed to various types of readers. They have been pruned of material which is no longer topical or relevant, but there are noither references nor index and the book is best regarded as essentially new. Prof. Revans himself suggests that the essays illustrate three common themes: the reed to apply the methods and attitudes of experimontal science to industrial practice; the subsequent emergence of exceedingly difficult problems which require more than known scientific method to solve them; and the comparatively elementary character of the study of management and the development of theory from such study. Fven more strikingly, the importance of clarity of thought and expression is emphasized throughout the book and exemplified in Prof. Revans's own prose, pointed and sometimes pregnant with prophetic authority. Beginning with a study of the sampling of attitudes on the shop floor, which strongly emphasizes this point about effective communication, the essays doal successively with decisions, communications and morale; science and the manager; technical knowledge; the pathology of automation; the scope of management control; industrial relations and industrial training; and the nature of operational research.

Prof. Revans's sense of the possibilities of using seience in management is matched by his sense of the limitations of the scientific method as well as a deep respect for human personality, and he has a rare capacity for going to the root of things. This study of technical knowledge and the essay on industrial relations and industrial training aro perhaps the best in the book and highly pertinent to Britain's present difficulties, outlining what needs to be done immediately. With so much good sense, constructive criticism and insight in this short volume, one wonders what Prof. Revans might have given us had he set out to discuss the technological society on the scale that Jacques Ellul has done. Perhaps he may yet give us a worthy successor to Bavink or Mumford.

R. BRightMan

\section{The Tissues of the Body}

By Prof. W. E. Le Gros Clark. Fifth edition. Pp. ix + 423. (Oxford: Clarendon Press; London: Oxford University Press, 1965.) 55s. net.

7 HE appearance of another edition of The Tissues of the Body. the fifth since its original publication in 1939, is itself some indication that this is no ordinary text-book. Sir Wilfrid Le Gros Clark is, of course, well known for his many and varied contributions to human and comparative anatomy, which gave impetus to the happy revitalization of academic anatomy that is now so much in evidence. Earlier editions of this, probably his best-known book, have exerted an intellectually stimulating effect on many medical students for whom the subject of anatomy might otherwise have seemed as inert as the dissecting-room specimens. In a diract and readable way the book succeeds in conveying the notion of anatomy as an exciting subject, with obvious relevance to bodily functions in health and disease. The author's wide experience of research is evident in the enthusiastic presentation of ideas and theories amenable to experimental investigation, rather than depending on mere preoccupation with morphological minutiae.

The present edition consists, as before, of thirteen self-contained chapters showing anatorny as basically the examination of biological organization at all levels: the cell, the tissue, the organ, the functional system and the integrated organism. The reader is offered not just factual information but reasoned interpretations based on the available evidence, with frequent indications of the actual limirs of existing knowledge. There are well-chosen references in the text, which may encourage the student to develop at an early stage the habit of looking up original work. The opportunity has been taken, with little increase in length, to revise many sections in the light of recent findings; arising especially from the application of newer techniques in the field of cell biology. A few electron micrographs, of adequate but not inspiring quality, are now included in the illustrations. One cannot help feeling that perhaps moro should have been done to emphasize the phenomenal scope of recent developments at the level of anatomical organization that is represented by molecular and cell biology. Nevertheless, this admirable book remains virtually in a class of its own, and ean be recommended unhesitatingly to students of medicine and biology.

J. A. Armstrono:

\section{Neurospora Bibliography and Index}

By Prof. Barbara J. Bachmann and Prof. W. N. Strickland. Pp. vii +225 . (New Haven and London: Yale University Press, 1965.) 4.00 dollars; $30 \mathrm{~s}$.

THE fungus Neurospora crassa is of outstanding significance in the development of biochemical genetics and it is attracting increasing attention as a research tool. It is therefore of very great value that a bibliography and index has been prepared as a guide to its literature. The first section of the volume is comprised of the bibliography itself, listing 2,310 papers and taking the record to January 1964. The references are listed alphabetically and each one is assigned a code number which is used in the index to refer to the paper. The second section is an. author cross-index. The third section indexes the subject matter of all papers in as much detail as has seemed useful. It is divided into three parts, a general index of subject matter, a mutant index and an index of Neurospora species other than $N$. crassa. Tests of the index have shown how effective it is. It appears from the preface that the indexes were the work of Dr. Bachmani, while the compilation of the references was done mainly by Dr. Strickland. Those who use this book (I hope $a$ growing number) will realize what a great debt is owed to the authors. They have provided an easy guide by which all information on a great variety of subjects can be quickly traced in a complex literature.

D. (A. Catcheside

Bananas

By N. W. Simmonds. Second edition. (Tropical Agriculture Series.) Pp.xvi $+512+106$ photographs. (London : Longmans, Green and Co., Ltd., 1966.) 63s. net.

$\mathrm{W}^{\mathrm{n}}$ HEN I reviewed the first edition of N. W. Simmonds's book Bananas (Nature, 186, 48; 1960), one of the "Tropical Agriculture Series", issued under the editorship of Mr. D. Rhind, I stated, with knowledge and convietion, that no book of equal status on this subject had hitherto been published. With the appearance of the second edition, I see no reason to change this view. However, a great deal that is new and interesting has happened in the banana industry since that time, and much of this has been successfully incorporated in the new edition. Accordingly, to those who are closely concerned with banana growing and all that is now involved in the harvest ing, packaging, transport and ripening of this sometimes fickle and always delicate crop, the new edition will commend itself as affording resdy access to the agricultural and scientific innovations in a highly competitive industry. In fact, it is quite surprising how many new and unexpected developments there have been. The preparation of the present volume has therefore involved extensive revision of the original text, the skilful splicing-in of critical new material at various points, and the incorporation of other quite new information of various kinds in a supplementary chapter-an overall enlargement of some forty-six pages. Like the first edition, this volume will prove instructive to a wide range of readers.

C. W. WARDLAW 